sulphate, and antihistamines are surprisingly deadly to young children. The report draws attention, too, to the value of advising old people about their own safety. Many do not clearly appreciate the risks they run from such ordinary domestic obstacles as a staircase or a slippery bath, let alone the hazards of the road. To reduce the last it is now generally conceded that individuals must accept a greater restriction on their freedom of action than nas been traditional by such measures as the imposition-and enforcement-of further speed limits ${ }^{6}$ and by a curb on the drinking of alcohol before driving.

In its own composition, as in its reports, the Accident Services Review Committee reflects the many-sided attack on the prevention of accidents and the provision of treatment for the injured that experience in recent years has shown to be necessary. A multiplicity of causes underlie most types of serious accident, while the treatment of the casualties may tax the resources of diverse specialists. The latest report of the Review Committee will be a useful stimulus to thought on these lines.

\section{College of Pathologists}

For an institution that is only two years old the College of Pathologists has gone far. Six years ago, when the formation of a college was first being mooted by the Association of Clinical Pathologists, we said of pathology in these columns: "If any discipline of medicine deserved to be recognized through the setting up of some institution, then pathology would have the highest claim, certainly now in this twentieth century of scientific medicine."1 As exponents of what is pre-eminently the basic clinical science pathologists have more than earned their right to collegiate status. In May 1963, less than a year after the unanimous vote at the founding meeting to set up a separate college, ${ }^{2}$ the College of Pathologists was firmly on its feet, and the names of its first president and council had been announced. ${ }^{3}$ In recognition of his personal distinction and his leadership in bringing the College into being, the 1,118 founding subscribers elected Sir Roy Cameron, F.R.S., as the first president, with Professor D. F. Cappell, Professor J. W. Howie, and Dr. A. G. Signy as vicepresidents. To-day Sir Roy Cameron still presides over the fortunes of the College. And in two years the membership has nearly doubled, standing now at over 2,000. This speedy growth greatly exceeds expectation: " no one could have predicted," says the College council in its annual report, ${ }^{4}$ "that [this figure] would be reached in such a short time." That the College could confer this year its honorary fellowship on such distinguished medical scientists as the President of the Royal Society, Sir Howard Florey, himself a former professor of pathology, the President of the Royal College of Physicians of London, Sir Charles Dodds, who made his name as a biochemist, and Dr. Peyton Rous, distinguished for his researches on cancer, augurs remarkably well for the College's future fame.

Education and standards of practice are of concern to any medical college, and it is not surprising to learn that the

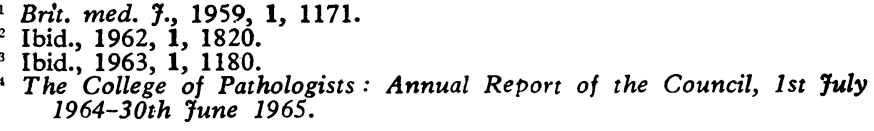

council of the College of Pathologists regards as its most important task the control of the College's examination system. For medically qualified pathologists there are now two primary examinations each year, in the spring and autumn. The primary is a broadly based examination, taken after two years' full-time work in pathology. The final examination, for which candidates are eligible after a further three years in the practice of pathology, is taken in one of four main branches of the subject-medical microbiology; histopathology and forensic pathology ; chemical pathology and toxicology ; or haematology. Non-medical pathologists such as some chemical pathologists and dental and veterinary pathologists can become members on the basis of their published work, but the College council is now considering the introduction of a suitably modified examination to meet their special requirements. This provision for non-medical membership reflects the close collaboration which nowadays so often exists at the laboratory bench-and elsewherebetween doctors and their scientific colleagues. This is the shape of the practice of medicine to come, and the College has been quick to give formal recognition to this fact of modern medical life. Concern with qualifications has led inevitably to review of the whole question of the training of pathologists and the facilities provided by laboratories in which the trainee pathologist is expected to work. The College is also concerning itself with the training of laboratory technicians.

There is no doubt that the M.C.Path. is already highly regarded. It has quickly taken its place alongside the similar diplomas of the older colleges as a guarantee of thorough grounding in the subject of pathology. The College council, which has acted energetically and with foresight, can rightly take much credit for this satisfactory state of affairs.

\section{Sickle-cell Anaemia and Anaesthesia}

When in 1949 Linus Pauling and his associates ${ }^{1}$ published a paper entitled "Sickle Cell Anaemia, a Molecular Disease" much that had previously been obscure became clear. Firstly, the mode of inheritance, as expounded by J. V. Neel, ${ }^{2}$ was explained. The abnormal sickle (S) haemoglobin was inherited through the action of a gene which could be derived from both parents to produce the homozygous condition (sickle-cell anaemia) or from one parent only to produce the heterczygous condition (sickle-cell trait). And secondly the molecular nature of the abnormality explained many of the clinical features of the disease.

Under conditions of reduced oxygen tension the $S$ haemoglobin in the red cells comes out of solution, and the resulting "crystallization" produces the bizarre, sickle-shaped cells. In sickle-cell anaemia the greater part of the haemoglobin is of the $S$ type, but there is a small fraction of foetal or $F$ haemoglobin which is resistant to denaturation with alkali. In the arterial blood in sickle-cell anaemia only about $5 \%$ of the erythrocytes are sickle-shaped, whereas after prolonged exposure to low oxygen tension $90-100 \%$ become so. These cells may block capillaries, venules, or even arterioles. If an area of skin affected by this process is examined, a tangled mass of these cells will be found held together in a loose fibrin mesh. In poorly vascularized areas, such as the lower leg, this may cause chronic ulceration. ${ }^{3}$ In patients with the 
sickle-cell trait less than half the haemoglobin is of the $S$ type, the rest being normal or type $A$, and very much lower oxygen tensions are required for intravascular sickling to occur. In consequence the sickle-cell trait is usually a benign condition and only under exceptional circumstances (such as flight in an unpressurized aircraft) can it cause symptoms. E. W. Smith and C. L. Conley ${ }^{4}$ described 14 cases of splenic infarction in patients with the sickle-cell trait. Most of the clinical features of sickle-cell anaemia can be attributed to infarction of various tissues in consequence of erythrostasis from sickled red cells. Pain in and about the joints is a prominent feature in about $80 \%$ of cases, ${ }^{5}$ and priapism and splenic infarction are fairly common. Pulmonary infarction is also seen and cerebral infarction may occur. ${ }^{6}$ Patients commonly present with abdominal pain, which may pose a difficult diagnostic problem. Surgical intervention is likely to produce disastrous results. The correct clinical diagnosis is not difficult provided it is considered, and a blood count, including examination of a stained film, is an essential precaution in Negro patients in whom surgery is contemplated.

When patients with sickle-cell anaemia have to undergo surgery it is clear that they are at special risk because of the possibility of hypoxia developing during the course of general anaesthesia. Where possible local or spinal anaesthesia or a nerve block should be used. Recently R. A. Browne ${ }^{7}$ reported, from the University Hospital of the West Indies in Jamaica, his experience of anaesthesia in 16 patients with sickle-cell anaemia who underwent surgical operations, and in view of the increasing numbers of immigrants to Great Britain some of the points which he makes are worth emphasizing. Patients with sickle-cell anaemia normally have a haemoglobin level between 5.5 and $8.5 \mathrm{~g} . / 100 \mathrm{ml}$., but pre-operative blood transfusion is best avoided if possible. Crises and even sudden death during transfusion have been reported, and iron overload is already a problem in this disease. Replacement of blood during surgical operation is of course indicated in the normal way, but care should be taken that normal blood only, of haemoglobin type $\mathrm{A}$, is used. The reticulocyte count should be checked pre-operatively, since a reticulocytosis is a healthy sign indicating an active bone-marrow. Infection should when possible be eradicated. Systemic acidosis enhances sickling, ${ }^{8}$ and therefore sodium bicarbonate $(0.5-1 \mathrm{~g}$. per $\mathrm{kg}$. body weight orally per day) should be given preoperatively to induce a metabolic alkalosis. This therapy can be continued for some days after operation.

During anaesthesia it is essential to avoid hypoxia such as may be caused by respiratory depression or obstruction. Doses of drugs for premedication should be small. Struggling or breath-holding during induction should be avoided, as also should deep anaesthesia and hypoventilation from any cause. Arterial hypotension is also dangerous. Administration of oxygen is beneficial, but if prolonged it may depress erythropoiesis, so a good compromise is to give $30-50 \%$ oxygen. The use of tourniquets to produce a bloodless field is fraught with danger unless the limb can first be exsangui-

Pauling, L., Itano, H. A., Singer, S. J., and Wells, I. C., Science, 1949, 110,543 .

2 Neel, J. V., ibid., 1949, 110, 64.

"Murphy, R. C., jun., and Shapiro, S., Ann. intern. Med., 1945, 23,

M76.
Smith, E. W., and Conley, C. L., Bull. Fohns Hopk. Hosp., 1955, 96, 35.

- Golding, J. S. R., MacIver, J. E., and Went, L. N., f. Bone ft Surg., 1959, 41B, 711

- Smith, E. W., and Conley, C. L., in Conference on Hemoglobin, 1958, p. 276. Publication 557, National Research Council. Washington, D.C.

Browne, R. A., Brit. 7. Anaesth., 1965, 37, 181

Greenberg, M. S., and Kass, E. H., Arch. intern. Med., 1958, 101, 355. nated. Browne concludes: "It is evident that patients with sickle-cell anaemia have very little reserve. The functional capacity of the vital organs is greatly reduced by infarction and fibrosis, as well as by the effects of severe anaemia. When anaesthetizing these patients, therefore, strict attention to details is essential. A small fall in oxygen saturation, especially in the presence of acidosis, is enough to cause sickling with its disastrous effects."

\section{Pension Increases}

The Pensions (Increase) Bill, which has had its first and second readings in the House of Commons, contains welcome news for many retired doctors. It provides for increases in the pensions of those who retired from certain public services on or before 1 April 1964. Among the public services are the Civil Service, the local-authority services, and both the hospital and the general practice sections of the National Health Service. The increases will start on 1 January if, as is likely, the Bill is enacted before the end of the year. Otherwise they will start on the first day of the month after the Bill is passed.

An increase of $16 \%$ is proposed for pensions that began on or before 1 April 1957. The increases proposed for pensions that began in subsequent annual periods beginning 2 April and ending 1 April are as follows: $14 \%$ (1957-8); $12 \% \quad(1958-9) ; 10 \%$ (1959-60) ; 8\% (1960-1); 6\% (1961-2); 4\% (1962-3); and 2\% (1963-4). These percentages will be applied to the existing rate of pension and will therefore be additional to any previous increases under earlier Acts. In general, pensioners other than child pensioners will not be eligible for an increase unless they are aged 60 or over ( 40 or over in the case of widows), or in bad health, or, in the case of women, have dependants.

There have been five Pensions (Increase) Acts since the N.H.S. began in 1948, the first being in 1952 and the last in 1962. The estimated cost of the current measure is $£ 18.2 \mathrm{~m}$. a year initially, of which about $£ 13 \mathrm{~m}$. will fall on the Exchequer and the remainder on the local rates. As in the case of the previous Acts, the cost will not fall on the National Health Service superannuation fund nor on the other superannuation schemes under which the pensioners concerned qualified for retirement benefits. The Bill does not affect armed Forces pensions, but the Government intends similarly to increase these under a separate measure.

Acts to increase pensions are intended to help to offset rises in the cost of living, and to the extent that they do so they are just, though many would agree that the increases should be related directly to increases in the cost of living since the date of retirement. For example, the increase in the cost of living since 1 April 1963 is $8.7 \%$ compared with the increase of $2 \%$ proposed in the new Bill. The Bill gives no increase for those who retired after 1 April 1964, though since then the cost of living has risen by $6.6 \%$. In a wider but related sphere, justice would also be served if the various earnings rules in the regulations governing statutory pension schemes and the payment of National Insurance retirement pensions were abolished. Like many other pensioners, retired doctors may still be capable of making a useful contribution to the common good. That in doing so they should have to forfeit some or all of their retirement pension seems wrong 